\title{
Human Fetal and Adult Chondrocytes

\author{
Effect of Insulinlike Growth Factors I and II, Insulin, and Growth Hormone on Clonal Growth
}

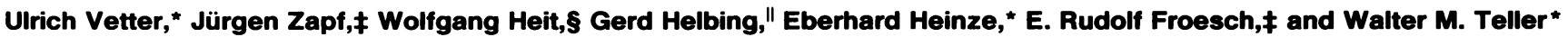

*Departments of Pediatrics, §Internal Medicine, and "Surgery, University of Ulm, D-7900 Ulm, Federal

Republic of Germany; and $\ddagger$ Department of Internal Medicine, University Hospital, CH-8091 Zürich, Switzerland

\begin{abstract}
Clonal proliferation of freshly isolated human fetal chondrocytes and adult chondrocytes in response to human insulinlike growth factors I and II (IGF I, IGF II), human biosynthetic insulin, and human growth hormone (GH) was assessed. IGF I (25 $\mathrm{ng} / \mathrm{ml})$ stimulated clonal growth of fetal chondrocytes ( $54 \pm 12$ colonies/ 1,000 inserted cells, mean \pm 1 SD), but IGF II $(25 \mathrm{ng} / \mathrm{ml})$ was significantly more effective $(106 \pm 12$ colonies $/ 1,000$ inserted cells, $P<0.05$, unstimulated control: $14 \pm 4$ colonies $/ 1,000$ inserted cells). In contrast, IGF I ( $25 \mathrm{ng} / \mathrm{ml})$ was more effective in adult chondrocytes ( $42 \pm 6$ colonies $/ 1,000$ inserted cells) than IGF II $(25 \mathrm{ng} / \mathrm{ml})(21 \pm 6$ colonies $/ 1,000$ inserted cells; $P<0.05$, unstimulated control: $6 \pm 3$ colonies $/ 1,000$ inserted cells). GH and human biosynthetic insulin did not affect clonal growth of fetal or adult chondrocytes.

The clonal growth pattern of IGF-stimulated fetal and adult chondrocytes was not significantly changed when chondrocytes were first grown in monolayer culture, harvested, and then inserted in the clonal culture system. However, the adult chondrocytes showed a time-dependent decrease of stimulation of clonal growth by IGF I and II. This was not true for fetal chondrocytes.
\end{abstract}

The results are compatible with the concept that IGF II is a more potent stimulant of clonal growth of chondrocytes during fetal life, whereas IGF I is more effective in stimulating clonal growth of chondrocytes during postnatal life.

\section{Introduction}

Human skeletal growth is influenced by a variety of hormones and growth factors. Cartilage is the important target tissue for prenatal and postnatal growth (1).

The stimulatory effects of hormones and growth factors on human skeletal growth can be assessed in an in vitro culture system that measures the proliferation of single chondrocytes to cell clones in a semisolid medium (2).

It is widely accepted that throughout postnatal life some of the actions of human growth hormone $(\mathrm{GH})^{1}$ are mediated by

Address reprint requests and correspondence to Dr. Vetter, Universitätskinderklinik, Prittwitzstr. 43, D-7900 Ulm, Federal Republic of Germany.

Received for publication 12 August 1985 and in revised form 12 February 1986

1. Abbreviations used in this paper: GH, human growth hormone; IGF I and II, insulinlike growth factors I and II.

J. Clin. Invest.

(c) The American Society for Clinical Investigation, Inc.

0021-9738/86/06/1903/06 \$1.00

Volume 77, June 1986, 1903-1908 the somatomedins/insulinlike growth factors (3). The direct growth promoting effect of insulinlike growth factor I (IGF I) has been demonstrated in hypophysectomized rats. Insulinlike growth factor II (IGF II) was clearly less active in these experiments $(4,5)$.

Whether or not $\mathrm{GH}$ acts directly on cartilage growth remains a matter of controversy. Most investigators have been unable to show any effect of GH on DNA or matrix synthesis of cartilage or chondrocytes in vitro $(6,7)$. Recently, Isaksson $(8)$ reported that GH injected locally into epiphyseal growth plates of hypophysectomized rats leads to a significant increase of growth plate width. Madsen $(9,10)$ demonstrated GH-stimulated thymidine incorporation and proteoglycan synthesis in high density chondrocyte cultures.

A possible activity of insulin on skeletal growth is suggested by the clinical observation that newborn infants of insulin-dependent diabetic mothers display macrosomia. However, continuous intrauterine infusion of insulin to the pregnant rhesus monkey leads to weight gain only and not to a significant increase in body length (11). In vitro insulin exerts mitogenic action on a variety of cells, including osteoblasts, fibroblasts, and chondrocytes; however, supraphysiologic concentrations are needed (12).

The role of IGF II in fetal and postnatal growth remains to be defined. In postnatal life, levels of IGF II are less growth hormone-dependent than those of IGF I (13). Changes in IGF I and II concentrations before and after birth have been described in the sheep and rat fetus and newborn lambs and rats. In the sheep, IGF I levels rise during gestation to low postnatal levels (14). In the rat fetus IGF I rises during late gestation, falls after birth, and rises again after day 15 of postnatal life (15). IGF II levels are significantly higher in all stages of gestation than during postnatal life in fetal lambs and rats $(14,15)$. However, this finding was not confirmed in humans. The concentration of IGF II in fetal and cord blood was significantly lower than during postnatal life $(16,17)$ or similar to the value found in the adult (18).

The present study was designed to determine whether or not insulinlike growth factors I and II, insulin, and growth hormone have a direct effect on the clonal growth of human chondrocytes, and to determine if their effects on clonal growth differ in fetal and postnatal chondrocytes.

\section{Methods}

Materials. Pure IGF I and II were generously supplied by Dr. Humbel, Institute of Biochemistry, University of Zürich, Switzerland $(19,20)$. Biosynthetic human insulin was purchased from Eli Lilly \& Co., Indianapolis, IN. Human growth hormone was kindly provided by Dr. Schleyer of the Proteohormon Laboratory of the University of Ulm, Federal Republic of Germany. Its specific activity was $2.5 \mathrm{U} / \mathrm{mg}$ protein.

Cartilage. Human fetal cartilage was obtained from the proximal and distal femoral epiphyses of four fetuses (18th-24th wk of gestation) 

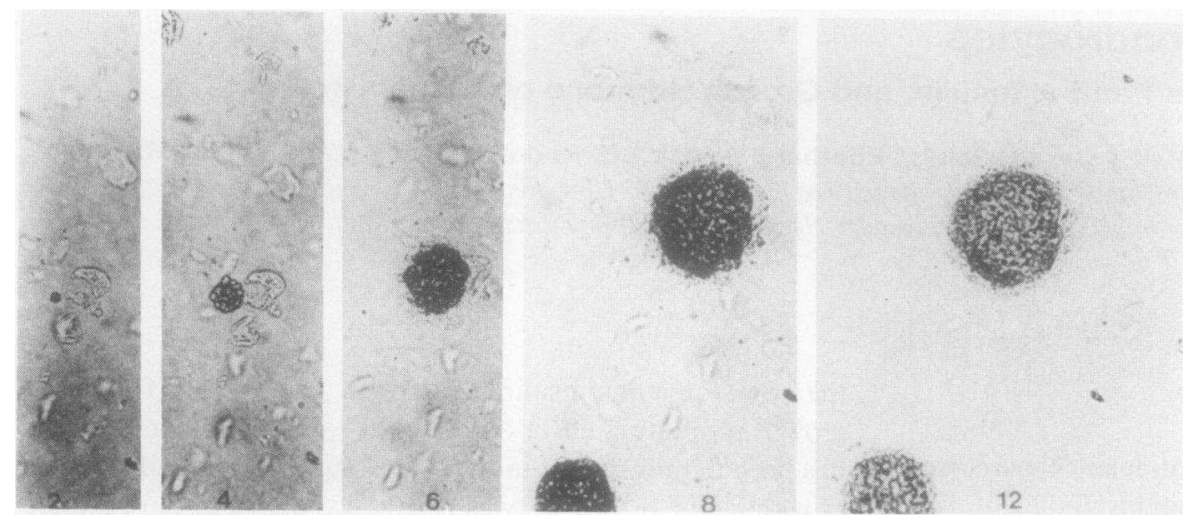

Figure 1. Colony growth of human fetal chondrocytes (day 2 through 12). At day 2 a four-cell stage is reached and at day 4 an eight-cell stage is reached; at day 12 a chondrocyte colony contains $\sim 50-60$ cells, and displays metachromatic staining and collagen type II by immunohistochemical staining (courtesy of Dr. K. von der Mark MPI, Munich) (magnification, $\times 125)$ (34).

after legal abortion. Adult articular cartilage from hip joints was obtained from three individuals aged 27-35 yr during surgery after accidental injury. None of the above fetuses or individuals had known endocrine or genetic disorders, degenerative or inflammatory disease, or generalized growth disturbances.

Isolation of chondrocytes. The cartilage was minced with a razor blade. The minced cartilage was transferred to $20 \mathrm{ml}$ Ham's F10 Medium containing $0.25 \%$ trypsin and $2 \mathrm{mg} / \mathrm{ml}$ of collagenase (CLS II; Worthington Diagnostics Div., Millipore Corp., Freehold, NJ) and incubated at $37^{\circ} \mathrm{C}$ for $30 \mathrm{~min}$ to remove adherent perichondrium and connective tissue. The incubation was stopped by the addition of $2 \mathrm{ml}$ fetal calf serum (FCS) and the incubates were centrifuged at $300 \mathrm{~g}$ for $10 \mathrm{~min}$. The sediment was resuspended in $20 \mathrm{ml}$ Ham's F10 Medium supplemented with 10\% FCS, 200 mM L-glutamin, Eagle's minimal essential medium (MEM)-multivitamins, and $2 \mathrm{mg} / \mathrm{ml}$ of collagenase, and was incubated for $16 \mathrm{~h}$ at $37^{\circ} \mathrm{C}$.

After digestion, a single cell sediment was obtained by centrifugation at $300 \mathrm{~g}$ for $10 \mathrm{~min}$. After resuspension of the cells in Ham's F10 Medium, the cell number and viability of the cells was determined by trypan blue exclusion. The viability of fetal and adult chondrocytes after isolation averaged $90-95 \%$. Microscopic evaluation proved that the chondrocytes were suspended as single cells and did not show aggregates.
Clonal proliferation assay of chondrocytes. The assay system used to measure the proliferative capacity of human chondrocytes was adapted from Bradley and Metcalf (2), who determined clonal proliferation of hematopoietic stem cells. The culture technique is based on the observation that the use of semisolid culture media prevents the sedimentation of cells and therefore enables proliferating chondrocytes to form colonies (21).

$1 \times 10^{3}$ chondrocytes were incubated in $100 \mu \mathrm{l} \mathrm{BM}$ Whissler Medium (Boehringer Mannheim, Federal Republic of Germany) per individual incubate supplemented with 5\% heat-inactivated FCS (FCS incubated for 60 min at $70^{\circ} \mathrm{C}$ ), $10^{-4} \mathrm{M}$ 2-mercaptoethanol, MEM-multivitamins, $40 \mu \mathrm{g} / \mathrm{ml}$ of gentamicin, $0.8 \%$ methylcellulose, and different concentrations of hormones and growth factors. The cultures were incubated without medium change for $14 \mathrm{~d}$ at $37^{\circ} \mathrm{C}, 5 \% \mathrm{CO}_{2}$, and $5 \% \mathrm{O}_{2}$ and $95 \%$ relative humidity. At the end of the incubation period the number of colonies per well was counted, 6-8 wells could be analyzed at different dose levels of hormones and growth factors (Fig. 1).

Monolayer culture of human fetal and adult chondrocytes. Freshly isolated chondrocytes were suspended in Ham's F10 Medium supplemented with $10 \%$ FCS, $10^{-4}$ mol 2-mercaptoethanol, $200 \mathrm{mM}$ L-Glutamin, MEM-multivitamins, and $40 \mu \mathrm{g} / \mathrm{ml}$ of gentamicin. Volumes of $5 \mathrm{ml}\left(5 \times 10^{5}\right.$ chondrocytes $\left./ \mathrm{ml}\right)$ were placed in Greiner culture flasks

Table I. Colony Formation of Human Fetal and Adult Chondrocytes

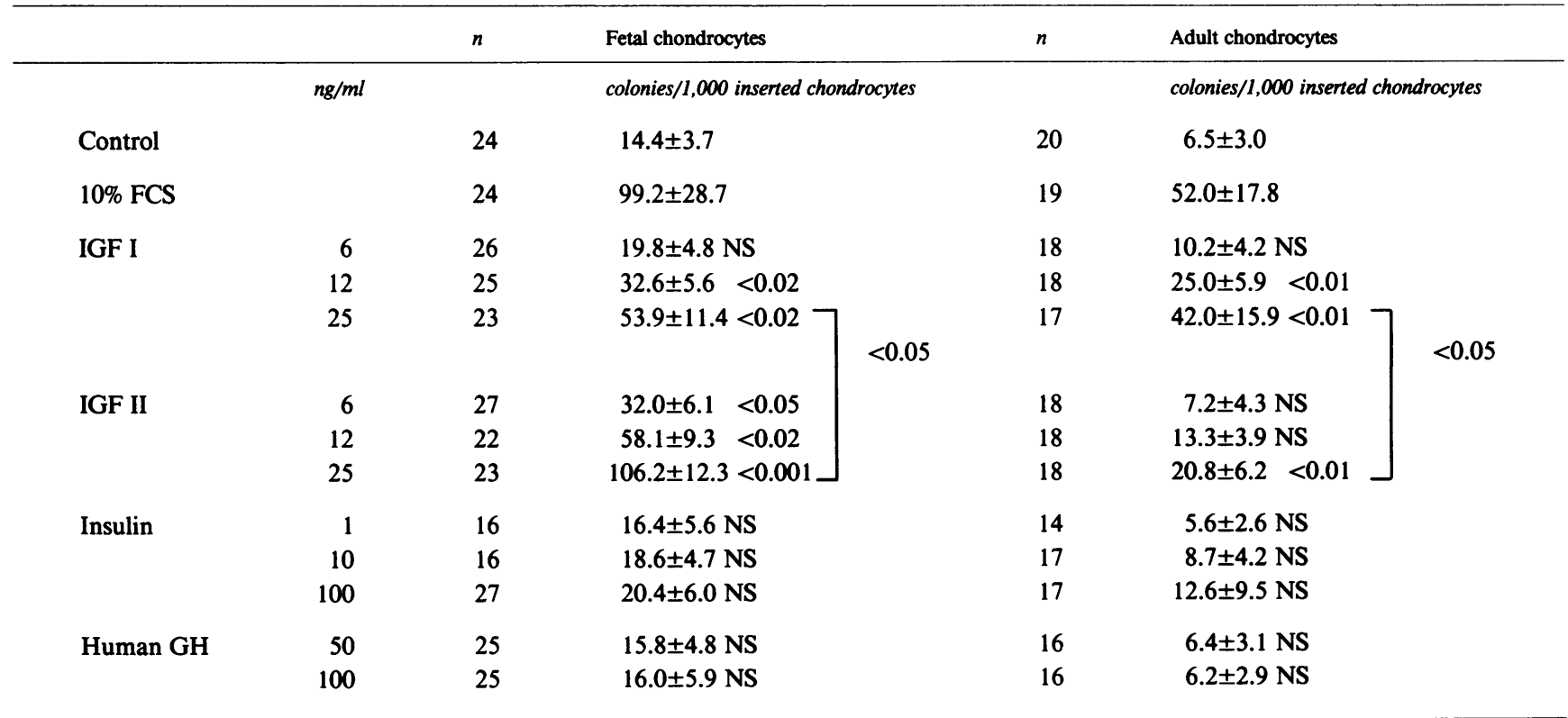

Colony formation of human fetal and adult chondrocytes stimulated by $10 \%$ FCS IGF I and II, insulin, and growth hormone (GH) (mean \pm 1 SD). $n$ represents the total number of dishes incubated in four independent experiments of isolated chondrocytes from four different fetuses, and three independent experiments of isolated chondrocytes from three adult donors. 
$\left(50 \mathrm{ml} / 25 \mathrm{~cm}^{2}\right)$ and incubated at $37^{\circ} \mathrm{C}, 5 \% \mathrm{O}_{2}$ and $5 \% \mathrm{CO}_{2}$ and $95 \%$ relative humidity. Every third day a complete change of the medium was performed. At days 8,15 , and 22 the monolayer was scraped off the bottom of the flask and incubated for $2 \mathrm{~h}$ at $37^{\circ} \mathrm{C}$ in Ham's F10 Medium supplemented with $10 \%$ FCS, 200 mMol L-Glutamin, MEM-multivitamins, and $2 \mathrm{mg} / \mathrm{ml}$ of collagenase (CLS II; Worthington Diagnostics Div., Millipore Corp.). At the end of the incubations the cell suspension was centrifuged at $300 \mathrm{~g}$ and the cell sediments were washed twice with $10 \mathrm{ml}$ Ham's F10 Medium. After resuspension of the cells in Ham's F10 Medium, the cell number and viability of the cells were determined as above.

The chondrocytes were then incubated in the clonal assay system as described above.

Statistics. Statistical analysis was performed using unpaired Student's $t$ test.

\section{Results}

Colony growth of freshly isolated fetal and adult chondrocytes. The results of clonal growth promotion by growth hormone, insulin, and insulinlike growth factors I and II of human fetal and adult chondrocytes are summarized in Table I. Growth hormone $(50$ and $100 \mathrm{ng} / \mathrm{ml}$ ) did not stimulate clonal growth of either fetal or adult human chondrocytes. Insulin $(1,10$, and $100 \mathrm{ng} / \mathrm{ml}$ ) also failed to enhance clonal growth of human fetal and adult chondrocytes. Insulinlike growth factor I at a concentration of $12 \mathrm{ng} / \mathrm{ml}$ and $25 \mathrm{ng} / \mathrm{ml}$ and insulinlike growth factor
II in all tested concentrations led to a significant stimulation of the clonal proliferation of fetal chondrocytes. Insulinlike growth factor II at a concentration of $25 \mathrm{ng} / \mathrm{ml}$ was significantly more effective than insulinlike growth factor $I(25 \mathrm{ng} / \mathrm{ml})$ in stimulating the clonal growth of fetal chondrocytes $(P<0.05)$.

Insulinlike growth factor I at a concentration of $12 \mathrm{ng} / \mathrm{ml}$ and $25 \mathrm{ng} / \mathrm{ml}$ and insulinlike growth factor II at a concentration of $25 \mathrm{ng} / \mathrm{ml}$ significantly stimulated clonal growth of adult chondrocytes. Insulinlike growth factor I $(25 \mathrm{ng} / \mathrm{ml})$, however, was more effective than insulinlike growth factor II in adult chondrocytes $(P<0.05)$. Both in human fetal and adult chondrocytes, insulinlike growth factors I and II showed a dose dependent pattern of clonal growth promotion.

Colony growth of fetal and adult chondrocytes after preincubation in monolayer culture. To investigate the influence of in vitro preincubation on the growth response pattern to insulin, GH, and IGF I and II, we grew human fetal and adult chondrocytes in monolayer culture for $22 \mathrm{~d}$. The colony formation of freshly isolated chondrocytes (day 0 ) was compared with the colony formation of chondrocytes that were harvested for at different times (days 8, 15, 22) during the 22-d monolayer culture. Fig. 2 shows the morphology of chondrocytes. By day 8 of culture, chondrocytes expressed a typical polygonal shape and were partially growing in clones in the monolayer. At day 22 the chondrocytes had lost their phenotype and became fibroblastic in morphology.

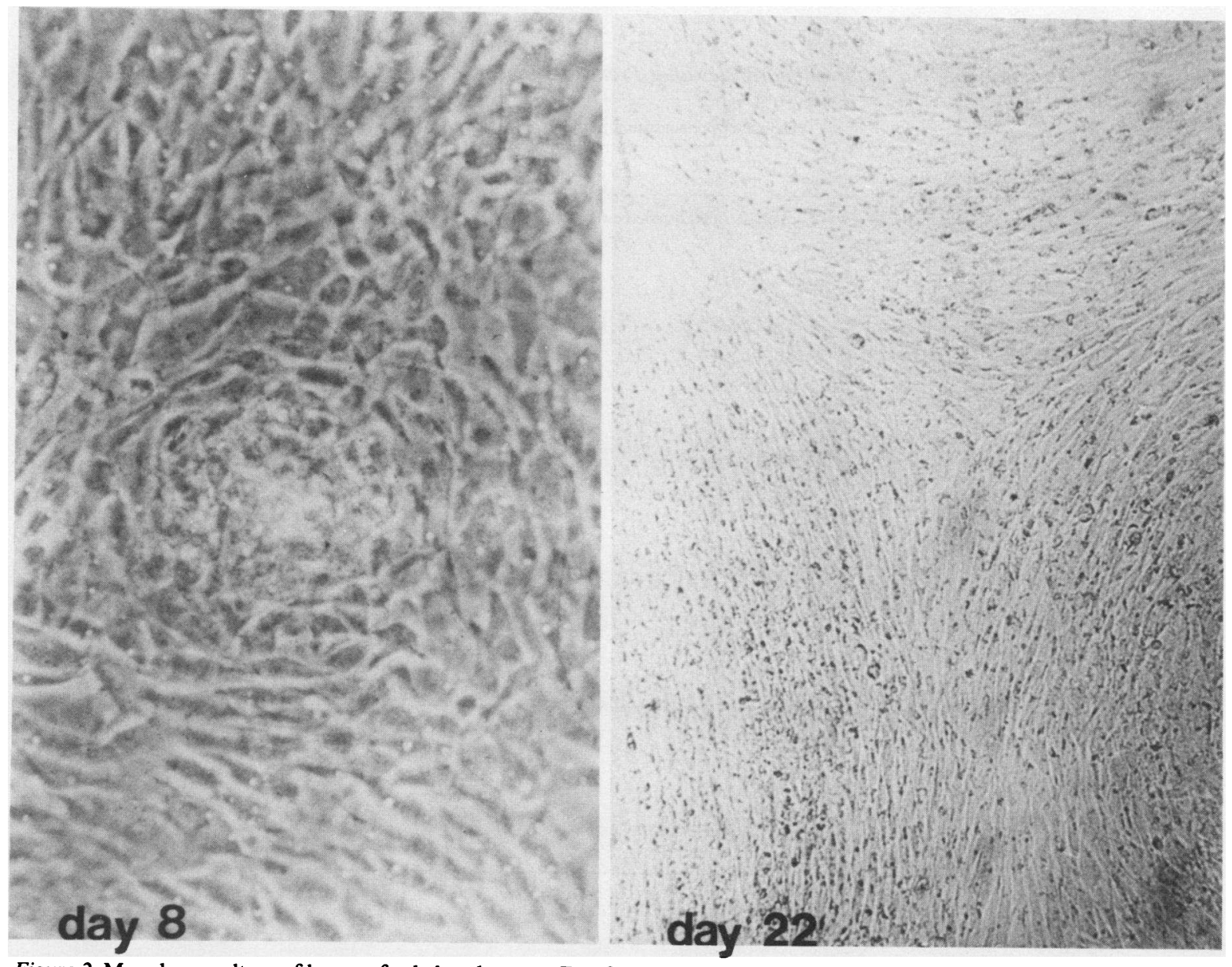

Figure 2. Monolayer culture of human fetal chondrocytes. Day 8, polygonal shape of chondrocytes that partly grow in colonies. Immunohistochemical analysis mainly shows collagen type II. Day 22, fibroblast-like appearance of dedifferentiated human fetal chondrocytes. Immunohistochemical analysis mainly shows collagen type I (magnification, day $8, \times 125$; day $22, \times 50$ ). 
GH and insulin did not stimulate the clonal growth of fetal and adult chondrocytes at any time (results not shown). IGF II $(25 \mathrm{ng} / \mathrm{ml})$ was significantly more effective in stimulating clonal growth of fetal chondrocytes than IGF I $(25 \mathrm{ng} / \mathrm{ml})(P<0.05)$ given. IGF I $(25 \mathrm{ng} / \mathrm{ml})$ was significantly more effective in stimulating clonal growth of adult chondrocytes than IGF II (25 ng/ ml) $(P<0.05)$ (Table II).

The stimulating effect of IGF I and II on fetal chondrocytes did not decrease relative to time in the preincubation period. In contrast, the stimulation of adult chondrocytes by IGF I and II diminished significantly $(P<0.01)$ between day 0 and 22 .

\section{Discussion}

There has been a longstanding interest in clarification of the stimulatory effects of insulin, GH, and IGF I and II on human fetal and postnatal growth. To investigate the direct mitogenetic action of these hormones and growth factors on skeletal growth, we studied the ability of human fetal and postnatal chondrocytes to proliferate in a clonal manner. Clonal growth is characteristic for chondrocytes in vivo and in vitro $(22,23)$. The assay system used enables the chondrocytes to proliferate in cell clones over a relatively long period of time and direct evidence of cell multiplication is gained in contrast to incorporation of labeled thymidin. This method merely defines cell populations that incorporate thymidin into the cell nucleus during S-phase of the cell cycle.
The direct action of IGF I and II has been demonstrated by systemic application to hypophysectomized rats $(4,5)$. IGF I was much more active in stimulating $\left[{ }^{3} \mathrm{H}\right]$ thymidine incorporation into tibial epiphyseal growth plate than IGF II. In our in vitro assay system, IGF I was twice as active as IGF II in promoting the clonal growth of human adult chondrocytes.

Special interest has been directed to the possible role of IGF II in fetal skeletal growth. Several studies in rats $(15,24)$ and sheep (14) have shown that a serum growth factor displaying IGF II-like properties is elevated during fetal life when compared to postnatal life. Rat fetal fibroblasts in culture released predominantly rat IGF II and only small amounts of rat IGF I (25). However, postnatal cultured rat fibroblasts released increasing amounts of rat IGF I and decreasing amounts of rat IGF II in an age-dependent manner (25). Our studies using chondrocytes isolated from midgestational fetuses showed that IGF II was twice as active in stimulating clonal growth as IGF I. These findings are suggestive of a role of IGF II in human fetal skeletal growth, although IGF II concentrations in cord blood are low compared with adult values (18). Whether these discrepancies in the effects of IGF can be explained by special physiochemical properties of the IGF binding proteins during fetal life remains to be clarified, since the IGFs are almost exclusively bound to the $50,000 \mathrm{~mol}$ wt subunit and not to the $150,000 \mathrm{~mol}$ wt subunit of the binding protein as in adult life (26). When human fetal and postnatal chondrocytes were grown in monolayer culture for up to $22 \mathrm{~d}$ and subsequently cultured at different times, in

Table II. Colony Formation of Human Fetal and Adult Chondrocytes after Preincubation in Monolayer Culture

\begin{tabular}{|c|c|c|c|c|c|}
\hline \multirow[b]{2}{*}{ Chondrocytes } & & \multirow[b]{2}{*}{ Freshly isolated } & \multicolumn{3}{|c|}{ Days after preincubation in monolayer culture } \\
\hline & & & 8 & 14 & 22 \\
\hline & $n g / m l$ & colonies $/ 1,000$ inserted cells & colonies $/ 1,000$ inserted cells & colonies 1,000 inserted cells & colonies $/ 1,000$ inserted cells \\
\hline \multicolumn{6}{|c|}{ 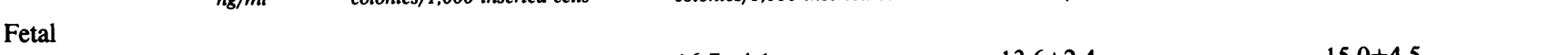 } \\
\hline Control & & $11.6 \pm 2.6$ & $16.7 \pm 4.1$ & $13.6 \pm 2.4$ & $15.0 \pm 4.5$ \\
\hline \multirow[t]{3}{*}{ IGF I } & 6 & $20.0 \pm 4.5$ & $19.2 \pm 4.5$ & $15.8 \pm 3.8$ & $15.0 \pm 4.1$ \\
\hline & 12 & $33.3 \pm 6.0$ & $36.4 \pm 5.4$ & $31.6 \pm 2.6$ & $32.5 \pm 4.2$ \\
\hline & 25 & $57.7 \pm 5.2$ & $60.0 \pm 5.4$ & $55.8 \pm 8.3$ & $70.0 \pm 5.0$ \\
\hline \multirow[t]{3}{*}{ IGF II } & 6 & $32.5 \pm 4.2$ & $30.7 \pm 8.9$ & $21.7 \pm 2.6$ & $30.0 \pm 3.2$ \\
\hline & 12 & $59.2 \pm 11.1$ & $56.6 \pm 6.0$ & $49.2 \pm 8.0$ & $67.0 \pm 5.7$ \\
\hline & 25 & $108.3 \pm 8.2$ & $97.5 \pm 14.0$ & $95.0 \pm 10.0$ & $99.2 \pm 5.8$ \\
\hline \multicolumn{6}{|l|}{ Adult } \\
\hline Control & & $17.5 \pm 4.2$ & $5.0 \pm 3.2$ & $8.3 \pm 4.0$ & $4.2 \pm 2.0$ \\
\hline \multirow[t]{4}{*}{ IGF I } & 6 & $28.0 \pm 5.7$ & $22.1 \pm 7.5$ & $13.3 \pm 2.6$ & $9.0 \pm 2.2$ \\
\hline & 12 & $56.0 \pm 4.1$ & $45.0 \pm 4.5$ & $27.5 \pm 4.2$ & $20.0 \pm 4.5$ \\
\hline & 25 & $88.0 \pm 7.6$ & $73.0 \pm 5.7$ & $50.8 \pm 8.0$ & $31.7 \pm 6.0$ \\
\hline & & \multicolumn{4}{|c|}{$P<0.01$} \\
\hline \multirow[t]{3}{*}{ IGF II } & 6 & $21.6 \pm 2.6$ & $8.3 \pm 2.6$ & $14.2 \pm 3.8$ & $3.0 \pm 2.7$ \\
\hline & 12 & $43.6 \pm 4.8$ & $28.3 \pm 3.3$ & $23.3 \pm 5.1$ & $11.7 \pm 6.0$ \\
\hline & 25 & $51.7 \pm 5.2$ & $38.3 \pm 7.5$ & $36.6 \pm 4.1$ & $18.3 \pm 2.6$ \\
\hline
\end{tabular}

Colony formation of human fetal and adult chondrocytes freshly isolated from cartilage and isolated from monolayer culture at days 8 , 14, and 22. Stimulatory effects of IGF I and II (mean \pm 1 SD). $n$ represents the number of dishes. The chondrocytes were obtained from one fetus (20th week of pregnancy) and one adult donor (age, $28 \mathrm{yr})$. 
our assay system the characteristic pattern of insulinlike growth factor I/II actions was not changed. The responsiveness of fetal chondrocytes to IGF I and II was not altered with increasing time of monolayer culture, whereas adult chondrocytes showed a time dependent decrease in responsiveness to both, IGF I and II, which might be due to a specific biochemical event such as a time-dependent loss of receptors during the preincubation of adult cultured chondrocytes.

The fetal and adult type responsiveness to IGF I and II obviously reflects a very stable gene expression which cannot apparently be changed under in vitro conditions such as those leading to a switch in the synthesis of type II to type I collagen (27).

In our in vitro assay system, growth hormone did not stimulate isolated human fetal and postnatal chondrocytes to proliferate in a clonal manner. This finding confirms the results of other investigators $(6,7)$, who were unable to demonstrate direct effects of growth hormone in different in vitro systems and clearly shows that growth hormone has no direct mitogenic effect on isolated chondrocytes. The observed increase of tibial width after local injection of growth hormone in hypophysectomized rats and the increased DNA and matrix synthesis in high density chondrocyte culture indicate that a possible direct action of growth hormone needs a special microenvironment which in itself might provide mediators for its action (8-10).

The growth stimulatory effect of insulin on cartilage and chondrocytes in in vitro systems has only been demonstrable using pharmacological doses (28). However, in a rat chondrosarcoma cell line $(29,30)$, physiological concentrations of insulin have been reported to stimulate matrix synthesis. Physiological insulin concentrations also stimulate collagen synthesis in fetal rat bone in vitro, which indicates that bone growth by matrix synthesis is enhanced by insulin. However, collagen synthesis in the subperiosteal cartilagenous cell layer representing appositional growth is not influenced (31). Administration of longacting insulin to hypophysectomized rats leads to increase in body weight and length (32). Intrauterine application of insulin, however, has failed to provoke an increase of fetal body length in fetal rhesus monkeys and pigs $(11,33)$. In our study, insulin, even at supraphysiological concentrations, did not significantly promote clonal growth of either human fetal or adult chondrocytes.

\section{Acknowledgments}

We thank Dr. N. Mathers, Department of Pediatrics, University of Sheffield, England, for editorial assistance. The skillful technical assistance of M. Schulz and the secretarial help of F. Schmelcher is gratefully acknowledged.

This research was supported by grants of the Deutsche Forschungsgemeinschaft, SFB 87 and 112.

\section{References}

1. Hinchliffe, J. R., and D. R. Johnson. 1983. Growth of cartilage. In Cartilage. Vol. 2. B. K. Hall, editor. Academic Press, Inc., New York. 255-295.

2. Bradley, T. R., and D. Metcalf. 1966. The growth of mouse bone marrow cells in vitro. Aust. J. Exp. Biol. Med. Sci. 44:287-299.

3. Daughaday, W. H., K. Hall, M. S. Raben, J. L. van den Brande, and J. J. van Wyk. 1972. Somatomedin proposed designation for sulphation factor. Nature (Lond.). 235:107-108.

4. Schoenle, E., J. Zapf, R. E. Humbel, and E. R. Froesch. 1982.
Insulin-like growth factor I stimulates growth in hypophysectomized rats. Nature (Lond.). 296:252-253.

5. Schoenle, E., J. Zapf, C. Hauri, Th. Steiner, and E. R. Froesch. 1985. Comparison of in vivo effects of insulin-like growth factors I and II and of growth hormone in hypophysectomized rats. Acta Endocrinol. 108:167-174.

6. Hill, D. J. 1979. Stimulation of cartilage zones of the calf costochondral growth plate in vitro by growth hormone dependent rat plasma somatomedin activity. J. Endocrinol. 83:219-227.

7. Mankin, H. J., A. Z. Thrasher, E. H. Weinberg, and W. H. Harris. 1978. Dissociation between the effect of bovine growth hormone in articular cartilage and in bone of the adult dog. J. Bone Jt. Surg. Am. Vol. 60A:1071-1075.

8. Isaksson, O. G. P., J. O. Jannson, and J. A. M. Ganse. 1982. Growth hormone stimulates longitudinal bone growth directly. Science (Wash. DC). 216:1237-1239.

9. Madsen, K., U. Friberg, P. Roos, S. Eden, and O. Isaksson. 1983. Growth hormone stimulates the proliferation of cultured chondrocytes from rabbit ear and rat growth cartilage. Nature (Lond.). 304:545-547.

10. Madsen, K., A. M. Makower, U. Friberg, S. Eden, and O. Isaksson. 1985. Effect of human growth hormone on proteoglycan synthesis in cultured rat chondrocytes. Acta Endocrinol. 108:338-342.

11. Susa, J. B., J. A. Widness, R. Hintz, F. Liu, P. Sehgal, and R. Schwartz. 1984. Somatomedins and insulin in diabetic pregnancies: effects on fetal macrosomia in the human and rhesus monkey. J. Clin. Endocrinol. Metab. 58:1099-1105.

12. Strauss, D. S. 1984. Growth stimulation actions of insulin in vitro and in vivo. Endocr. Rev. 5:356-369.

13. Zapf, J., E. Rinderknecht, R. E. Humbel, and E. R. Froesch. 1978. Nonsuppressible insulin-like activity (NSILA) from human serum: recent accomplishments and their physiologic implications. Metabolism. 27:1803-1828.

14. Gluckman, P. D., and J. H. Butler. 1983. Parturition related changes in insulin-like growth factor I and II in the perinatal lamb. $J$. Endocrinol. 99:223-232.

15. Daughaday, W. H., K. A. Parker, S. Borowsky, B. Trevedi, and M. Kapadia. 1982. Measurement of somatomedin-related peptides in fetal neonatal and maternal rat serum by insulin-like growth factor (IGF) I radioimmunoassay, IGF II radioreceptorassay (RRA) and multiplication stimulating activity RRA after acid-ethanol extraction. Endocrinology. 110:575-581.

16. Benett, A., D. M. Wilson, F. Liu, R. Nagashima, R. G. Rosenfeld, and R. L. Hintz. 1983. Levels of insulin-like growth factors I and II in human cord blood. J. Clin. Endocrinol. Metab. 57:609-612.

17. Ashton, J. K., J. Zapf, J. Einschenk, and J. Z. Mac Kenzie. 1985. Insulin-like growth factors I and II in human fetal plasma and relationship to gestational age and fetal size during midpregnancy. Acta Endocrinol. (Copenh.) 110:558-563.

18. Gluckmann, P. D., J. J. Barrett-Johnson, J. H. Butler, B. Edgar, and T. R. Gunn. 1983. Studies of insulin-like growth factors I and II by specific radioligand assays in the umbilical cord blood. Clin. Endocrinol. 19:405-413.

19. Rinderknecht, E., and R. E. Humbel. 1978. The amino acid sequence of human insulin-like growth factor I and its structure homology with proinsulin. J. Biol. Chem. 253:2769-2776.

20. Rinderknecht, E., and R. E. Humbel. 1978. Primary structure of human insulin-like growth factor II. FEBS (Fed. Eur. Biochem. Soc.) Lett. 89:283-286.

21. Vetter, U., W. Heit, G. Helbing, E. Heinze, and W. Pirsig. 1984. Growth of the human septal cartilage: cell density and colony formation of septal chondrocytes. Laryngoscope. 94:1226-1229.

22. Coon, H. G. 1966. Clonal stability and phenotypic expression of chick cartilage cells in vitro. Proc. Natl. Acad. Sci. USA. 55:66-73.

23. Watanabe, K. 1970. Changes in the capacity for clonal growth and differentiation in vitro of the vertebral cartilage cells with embryonic development. II. Vitalizing effect of conditioned medium. Dev. Growth Differ. 13:107-113.

24. Moses, A. C., S. P. Nissley, P. A. Short, M. M. Rechler, R. M. 
White, A. B. Knight, and O. Z. Higa. 1980. Increased levels of multiplication stimulating activity, an insulin-like growth factor in fetal rat serum. Proc. Natl. Acad. Sci. USA. 77:2782-2785.

25. Adams, S. O., S. P. Nissley, S. Handwerger, and M. M. Rechler. 1983. Development patterns of insulin-like growth factor I and II synthesis and regulation in rat fibroblasts. Nature (Lond.). 302:150-153.

26. D'Ercole, J., D. F. Wilson, and L. Underwood. 1980. Changes in the circulating form of serum somatomedin C during fetal life. J. Clin. Endocrinol. Metab. 51:674-676.

27. Gauss, V., and P. K. Müller. 1981. Change in the expression of collagen genes in dividing and non dividing chondrocytes. Biochem. Biophys. Acta. 652:39-47.

28. Lebovitz, H. E., and G. S. Eisenbarth. 1975. Hormonal regulation of cartilage growth and metabolism. Vitam. Horm. 33:575-648.

29. Stevens, R. L., S. P. Nissley, J. H. Kimura, M. M. Rechler, A. J. Kaplan, and V. C. Hasall. 1981. Effects of insulin and multiplications-stimulating activity on proteoglycan biosynthesis in chondrocytes from the swarm rat chondrosarcoma. J. Biol. Chem. 256:2045-2052.
30. Bembenek, M. E., D. H. Willis, and J. P. Liberti. 1982. The effect of insulin on collagen production in isolated chondrocytes. Biochem. Biophys. Res. Commun. 106:338-345.

31. Kream, B. E., M. D. Smith, E. Canalis, and L. G. Raisz. 1985 Characterization of insulin on collagen synthesis in fetal rat bone. En docrinology. 116:296-302.

32. Salter, J., and C. Best. 1953. Insulin as a growth hormone. $\mathrm{Br}$. Med. J. 2:353-356.

33. Spencer, G. S. G., D. J. Hill, G. J. Garsson, A. A. McDonald, and B. Colenbizander. 1983. Somatomedin activity and growth hormone levels in body fluids of the fetal pig: effect of chronic hyperinsulinaemia. J. Endocrinól. 96:107-114.

34. Mark, H. von der, K. von der Mark, and S. Gray. 1976. Study of differential collagen synthesis during development of the chick embryo by immunofluorescence. I. Preparation of collagen type I and II specific antibodies and their applications to early stages of the chick embryo. Dev. Biol. 48:237-249. 